\title{
Social capital, community-based governance and resilience in an African artisanal river fishery
}

\author{
BA Nkhata ${ }^{1}$, CM Breen ${ }^{1 *}$ and A Abacar ${ }^{2}$ \\ ${ }^{1}$ Centre for Environment, Agriculture and Development, University of KwaZulu-Natal, Private Bag X01, Scottsville 3209, South Africa \\ ${ }^{2}$ Zinave National Park, National Directorate of Conservation Areas, Ministry of Tourism, Mozambique
}

\begin{abstract}
This is a study of a community-based fishery on the Rovuma River that forms the border between Mozambique and Tanzania. We postulate a relationship between social capital and community-based governance over access to and the use of the fish resource. In historical times social capital was high and community-based governance regulated access to and use of the fishery as a common property resource. Transforming forces particularly colonial administration, advocating Christianity, war and an emerging market economy undermined social capital, which in turn affected community-based governance. The deconstruction of social capital has resulted in attitudes and behaviours that challenge governance processes with dire consequences for sustainable resource utilisation. Harvesting of fish stocks occurs at levels that are no longer sustainable and inappropriate practices are being adopted. While the Mozambique government policy promotes community-based fisheries management in artisanal fisheries, we argue that under current conditions of ineffective community-based governance, a strong focus on reconstruction of social capital will be required before a community-based resource management process can be effectively implemented. The findings are discussed in the context of resilience in social ecological systems. We suggest that given the historical context in which community-based natural resource management is promoted within southern Africa such a focus may have wide relevance.
\end{abstract}

Keywords: social capital, governance, property rights, CBNRM, resilience, river fishery

\section{Introduction}

Attempts to introduce and sustain community-based natural resource management (CBNRM) have met with mixed success. While some authors have claimed high incidences of failure (Campbell et al., 2001; Dzingirai and Breen, 2005; Fabricius, 2004), others have suggested that because CBNRM has the attributes of a complex system, emergent forces continually challenge stability such that phases of success, collapse and reconstruction should be anticipated (Anstey, 2005; Jones, 2005; Gunderson and Holling, 2002). It has been argued that instability arising from complex emergent forces usually leads to heightened uncertainty. Building on this understanding, it has been suggested that coping with uncertainty requires learning and adaptation of governance practices such that CBNRM is viewed as being complex and involving continuous problem-solving processes, rather than fixed state solutions (Carlsson and Berkes, 2005; Gunderson and Holling, 2002; Berkes et al., 2003).

Phases of change are inherently common in complex human processes such as CBNRM. Fabricius and Collins (2005) draw attention to a number of 'classic surprises' that are associated with phases of discontinuous change in CBNRM. Among these are conflict (Koch, 2004), financial mismanagement (Robbins, 2000), and mismanagement of natural resources (Okello and Kiringi, 2004). Elsewhere, Anderies et al. (2004) have drawn attention to why simple social-ecological systems (SESs) can be robust over very long periods of time and how they can collapse rather rapidly in response to disturbances. The evidence

\footnotetext{
* To whom all correspondence should be addressed.

푱 +2733 2605775; fax: +2733-2606118;

e-mail: breen@mweb.co.za

Received 29 February 2008; accepted in revised form 14 October 2008.
}

presented by these and other authors generally points to the understanding that change is an inherently pervasive variable in CBNRM processes. However, most approaches to interpreting such change have been inadequate partly because they typically describe the development of CBNRM from initiation to stability.

In this paper, we consider social capital as a major regulator of discontinuous change in the governance processes of CBNRM. Given the support that social capital lends to the attributes of governance in the use and management of common property resources, we argue that social capital directly affects relationships among interest groups in a governance system and hence serves to buffer against destructive change in property rights regimes that would threaten sustainability. Volatility in social capital is reflected in the transformation of property rights regimes and tests the resilience of governance to respond to systemic forces. We draw on a study of the Rovuma River fishery postulating that the fishery was originally conducted in the context of common property (use of a resource with controls) that persisted for a long time. This property rights regime has over time changed to open access (use of a resource without or with ineffective controls) (Abacar, 2000). Drawing on resilience theory, we develop postulations that can be used to examine the forces that have directed this change. Our postulations, however, should be construed as a related set of explicit assumptions that can be used to better understand and improve CBNRM. We, of course, acknowledge that our assumptions are inherently incomplete and will evolve as new understandings of CBNRM processes emerge. Issues that are strongly related to resilience in common property resources form the basis of our assumptions. Accordingly, we believe that effective CBNRM should be founded on well-developed social capital that lends support to resilient and socially acceptable governance processes. 


\section{Property rights and governance}

Arguably, the nature and substance of governance systems affect the sustainability of common property resources. Ostrom (1990) and later Anderies et al. (2004) have proposed governance design principles (including rules, rule making and enforcement) that could be attributed to enduring common property resource management institutions. Enduring in this context does not simply imply that there is some idealised or steady system state but rather that the institutions are resilient (Walker, 1989) or robust (Anderies et al., 2004). Resilient institutions are able to adapt to continually changing circumstances, thereby sustaining the structure and function of SESs. Important for this study, resilience confers an ability to maintain desirable governance system properties despite fluctuations in structure and function.

Rhodes (1996) has suggested that one definition of governance might be 'self-organising networks'. Such networks are known to have the propensity to move through adaptive cycles involving four key phases: monopoly and conservation of structure; release and collapse; reorganisation and renewal; and growth to a potentially new monopolistic phase (Holling, 1973, 1995; Gunderson and Holling, 2002; Ostrom and Janssen, 2002). Anstey (2005:144), considering the potential phases of CBNRM, has observed that 'conservative phases may remain over long periods, injustice or inequality in key systems may become more resilient and undesirable configurations can persist.' In this way, we can envisage that the reorganisation and growth phases involve a renewal of governance. We suggest that to determine whether there is reorganisation and/or growth, we would have to consider the transformation of property rights regimes.

Property rights regimes are complex institutional structures and rules (formal and informal) that include both rights to access as well as rights to exclude from access (Schlager and Ostrom, 1992). Property to which a community of people may rightfully claim access and use constitutes a common property. Because there are usually rules governing how members of the community access and use the common property or resource (examples in Berkes et al., 2003), property rights 'encompass a diverse set of tenure rules and other aspects of access to and use of resources' (Meinzen-Dick et al., 1997:1303). Security of tenure is central to the notion of property rights (Gibbs and Bromley, 1989) and thus if we understand property rights to refer to an individual's capacity to call upon the collective to stand behind his or her claim to a benefit stream (Bromley, 1991), then property rights essentially describe relationships between people.

Conceptualising property rights from the perspective of relationships supports the contention of Ostrom (1990) that social homogeneity is important in management of use and access to common property. Not surprisingly, Singleton and Taylor (1992) consider that the term 'community' has been central to the evolution of viable commons institutions. Thus, in seeking to establish whether the Rovuma fishery may have transformed from a common property to an open access regime, we argue that it would be necessary to establish that there existed dynamic relationships among those claiming rights of access to and use of the resource and with those that supported the allocation of rights of access and use of the resource. We contend that we cannot fully understand the effects of governance on resource sustainability without an understanding of how the underlying relationships help to shape property rights regime.

\section{Social capital as an expression of relationships}

Different authors use different ways to define and character- ise social capital. Some approach the concept with terms such as norms and networks (see Coleman, 1990). Such terms refer to structures that emerge and constrain social interactions (Granovetter, 1985; Knoke, 1990). These structures are typically represented as socio-grams that illustrate the links among community members (Newman and Dale, 2005). For others, social capital refers to the stock of socio-psychological attributes of relationships including trust and commitment. Whilst the two attributes are not necessarily the only forms of social capital, most theorists view them as particularly important determinants of the nature of relationships. Trust, for example, is viewed as a socio-psychological state in which a party to a relationship adopts a belief that the other party will not act against its interests (Luo, 2002). As a socio-psychological state, trust evolves from an actor's past experience, current interactions, and expectations. Commitment, on the other hand, refers to the energies and resources invested by a party in building long-term relationships. It denotes the extent to which the party believes that a relationship is worth expending energies on. Importantly, it evinces the readiness of the party to do more than is formally expected (Luo, 2002).

For the purposes of this paper, we adopt a more holistic and pragmatic approach to defining social capital. We proceed by searching for a unifying framework in which we incorporate the most important insights of different perspectives. Accordingly, we conceive social capital as comprising behavioural attributes that include trust, commitment, respect, networks and norms. Our interest is the behaviour of actors over time (Pettigrew, 1973; 1990). From this perspective, the social capital that embodies relationships in the management of common property is construed not as entities, but rather as a consequence of dynamic behavioural processes. As with all behavioural processes, social capital should be viewed as having outcomes, no matter how definable or indefinable those outcomes may be (see Cousins, 2002; Kinnaman and Bleich, 2004). Such a perspective denotes how adaptations in behavioural interactions take place between actors. Accordingly, in seeking to determine what role social capital may have played in the Rovuma fishery, we have to consider evidence for how adaptations provided premises on which actors rationalised their behavioural styles and how the actors responded to potentially disruptive forces. To determine whether there was collapse and reorganisation in the property regime, we have to consider the possible pathways for the development of social capital.

Putnam (1993) argues that social capital can make an important contribution to improving society's capacity to overcome social dilemmas, such as those that might arise in the use and management of a common property regime. It is this capacity that may foster resilience in governance over the allocation and use of the common property. Dekker and Uslaner (2001) suggest that social capital contributes to enforcing norms, supporting the view of Metcalfe (1994) who observed that communal resource management is enhanced if it is small enough for all members to meet face to face, to enforce conformity with rules through peer pressure, and to create long-standing identity. Anderies et al. (2004) extend these concepts into governance design principles for robust SESs stressing the importance of 'clearly defined boundaries', 'proportionality of benefits' and of 'local users establishing harvesting and protection rules' for resource use. Not surprisingly, Plummer and FitzGibbon (2006) conclude that social capital has a fundamental role in developing co-management systems of river corridors.

Inherent in the foregoing interpretations is that social capital would help to counter forces tending to disrupt a common 


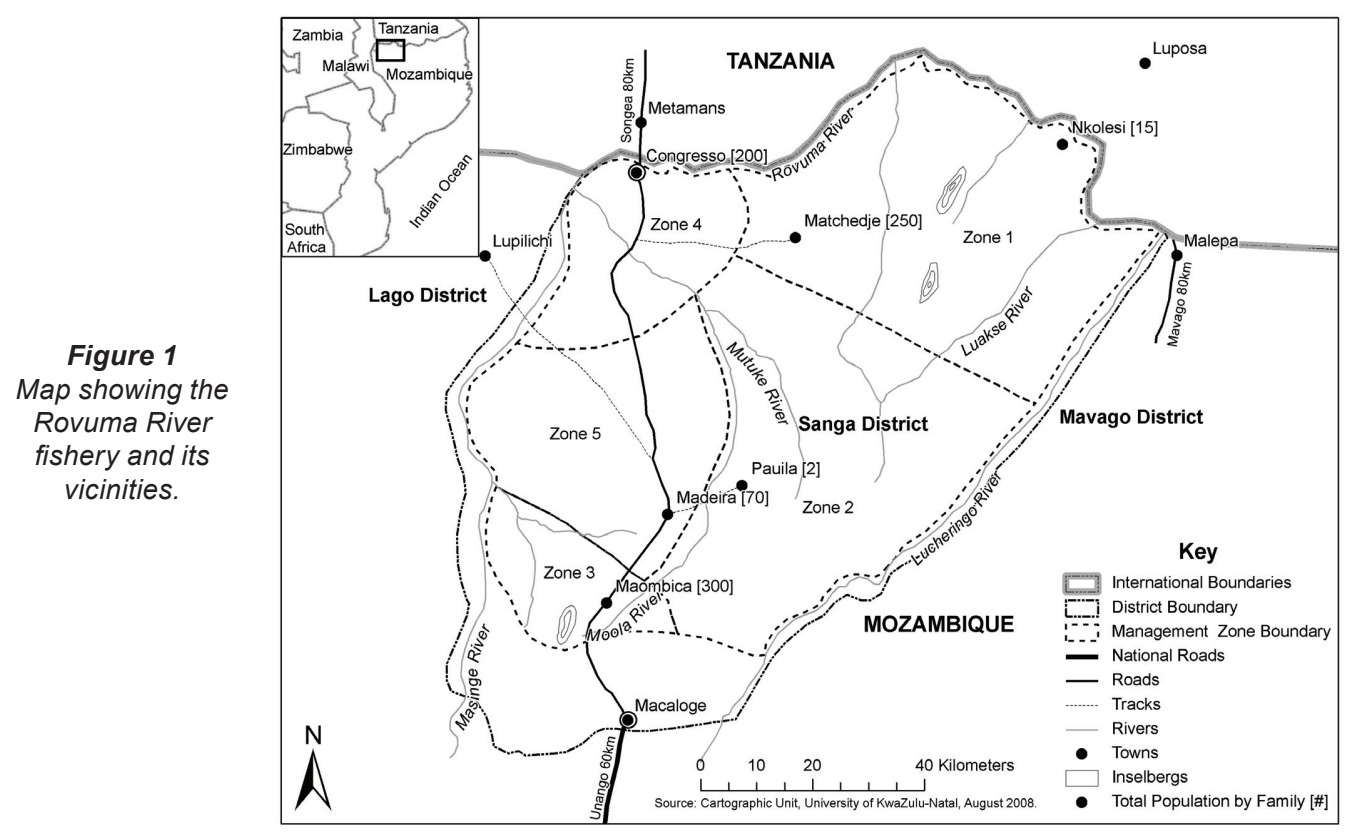

property regime. Bridger and Luloff (in Stokowski, 2003) suggest that successful cooperation for long term mutual benefit in the management of common property depends on cultivation of social capital. It follows that in circumstances where a legitimate common property regime has 'collapsed' and been replaced by an illegitimate open access regime that is perceived to be undesirable, the community would need to reconstruct social capital during reorganisation and growth before a new state can emerge. The successful operation of a community-based fishery governance system clearly depends on the relationships among those who fish and the greater community through whom the rights to fish are negotiated and allocated. Such a network of relationships (founded on norms, trust, commitment and respect for neighbours and leaders) is what we refer to as social capital.

\section{The study area and methods}

\section{Study area}

This study focused on the fishery that operates on the Rovuma River as well as the floodplain between the Lucheringo and Messinge tributaries (Fig. 1). The Rovuma River captures the Lucheringo and Messinge tributaries draining northwards and defines the boundary between Mozambique and Tanzania. The fishery exploits the rivers and lakes that form along the floodplains. This area forms the northern part of a CBNRM initiative, the Chipanje Chetu Project, which has been supported by the World Conservation Union (IUCN) and Mozambique Government Department of Wildlife and Forestry (IUCN, 1998). It should be noted that the case study presented herein is neither meant to be comprehensive nor exhaustive; rather it is only designed to be exploratory and illustrative. While the inclusion of areas on the Tanzanian side could perhaps have provided valuable insights, time and logistical constraints limited the study to just the Mozambican side. Nevertheless, the case study is still instructive particularly in illustrating why and how discontinuous change occurs in CBNRM processes.

The Yao or Ajauas are reputed to be the indigenous inhabitants of this area which is presided over by a traditional chief locally known in Yao language as 'Mwenye' and his N'dunas or headmen (Amaral, 1990). Bunn and Auslander (1998) consider it likely that in the pre-colonial era, before present-day political boundaries were defined, those who used resources of the river and its floodplains were drawn from north and south, and were 'one' despite the inexactness of border identities. The Yao have come under the religious influences of Islam and, since the arrival of the Portuguese possibly in the $15^{\text {th }}$ century but more significantly since the $18^{\text {th }}$ century (Anstey, 2005), of Catholicism. However, most people in the study area $(90 \%)$ follow Islam. During the war of liberation and the subsequent civil war many people fled to Tanzania. Nowadays, Kiswahili is the dominant language among young people of the area (Abacar, 2000; Anstey, 2005).

Agriculture is the predominant subsistence activity but production levels do not constantly meet household nutritional needs (Rachide, 1999 in Abacar, 2000). Fish is the most important traded resource and harvesting is considered to be at levels that cannot be sustained (Anstey, 2005; Abacar, 2000).

\section{Methods}

The study employed the approach of qualitative field research as its core scientific methodology. This was premised on the understanding that the neglect of the analysis of behavioural processes in collaborative natural resources management (Nkhata et al., 2008) necessitates a qualitative field research methodology to facilitate a processual framing of field situations. This methodology is essentially concerned with non-numerical data, as opposed to numerical data which are essentially a purview of quantitative research (Babbie, 1995). According to Strauss and Corbin (1998), qualitative field research is largely a nonmathematical process of interpreting data through discovering linkages between concepts and themes. It is mostly concerned with theory generated from the study of small scale populations. Qualitative field research does not only provide a means for gathering data, but also a way for building knowledge about the social world. Although this methodology is primarily concerned with field settings, there are many different methods that one can use to gather qualitative field data. To mitigate the inherent threats to validity posed by the many different qualitative data gathering methods, this study had to use multiple methods and data sources. 


\begin{tabular}{|l|c|}
\hline \multicolumn{2}{|c|}{ TABLE 1 } \\
List of key informants interviewed during the study \\
\hline Category of respondents & Number \\
\hline Elders & \\
\hline $\begin{array}{l}\text { Village representatives } \\
\text { Madiera village secretary }\end{array}$ & 1 \\
\hline Traditional chiefs & \\
$\quad$ Mwenye/Sultan & 1 \\
$\quad$ N'duna & 4 \\
\hline Village council/committee & \\
$\quad$ Madiera local council/committee & 2 \\
$\quad$ Matchedje local council/committee & 2 \\
\hline Sub-total & 10 \\
\hline Artisans & \\
\hline Fishermen & 46 \\
\hline Fish processors & 4 \\
\hline Sub-total & 50 \\
\hline GRAND TOTAL & 60 \\
\hline
\end{tabular}

To assess the evolution of community-based governance, data was gathered using a combination of extensive documentary analysis, focus group interviews and structured and unstructured interviews with individuals (Saunders et al., 1997). The interest was in detecting change in time rather than gathering detailed factual information on community-based governance. The same set of questions was put to each respondent who had lifetime experiences of the area and issues at hand. Respondents, however, were also given opportunity to elaborate and the researcher was able to probe and seek clarity of the meaning of responses. Upon arrival at a village the researcher introduced himself to the headman (N'duna) and sought permission to conduct research. The N'duna then called together senior advisors numbering between 2 and 4 . These constituted the 'focus groups' who responded to the questionnaire and with whom there was lively discussion. Through the focus groups the key informants (Kumar, 1989) were identified and subsequent respondents were identified using the chain referral sampling method (Babbie, 1995). It was not possible to interview all those who were recommended as some were not available during the field work. Ten elders and 46 fishermen and 4 fish processors were interviewed (Table 1). Six people identified by the focus groups and drawn from 2 villages (Madiera and Machedje) volunteered as guides and introduced the researcher to respondents.

\section{The changing context of governance}

In this section we offer a perspective of the changing context of governance in the Rovuma fishery. We argue that a resilience approach offers useful perspective for the study of change in community-based governance, especially as it relates to common property regimes. We suggest that the property rights regime of the Rovuma community-based governance system has over time transformed from a common property to an open access regime. We propose a framework that represents the phases of an adaptive cycle of the Rovuma community-based governance system to interpret the nature and substance of this transformation. The framework is used to determine the potential for change based on the amount of social capital. The elements of social capital are proposed as a foundation for resilience in community-based governance. It is from the perspective of social capital that behavioural processes are vital in interpreting change in the property rights regimes that underlie community-based governance. In this context, change is defined by the degree of stability and instability of social capital. Social capital provides the basis of change to the extent that it enables a property rights regime to develop, mature, collapse, and reorganise based on adaptations. As shown in Fig. 2, the property rights regime of the Rovuma community-based governance system has over time gone through phases of an adaptive cycle from a conservation phase through release into a reorganisation phase.

\section{Conservation phase}

From a resilience perspective, a conservation phase is one in which social capital is well consolidated (Nkhata et al., 2008). It is essentially an emergent phase whereby slow accumulation of social capital results in complex structures of interactions among resource users. The property rights in this phase have the advantage of functioning through cooperative rather than market or bureaucratic instruments (Huxham, 1996). Thus, it is pos-

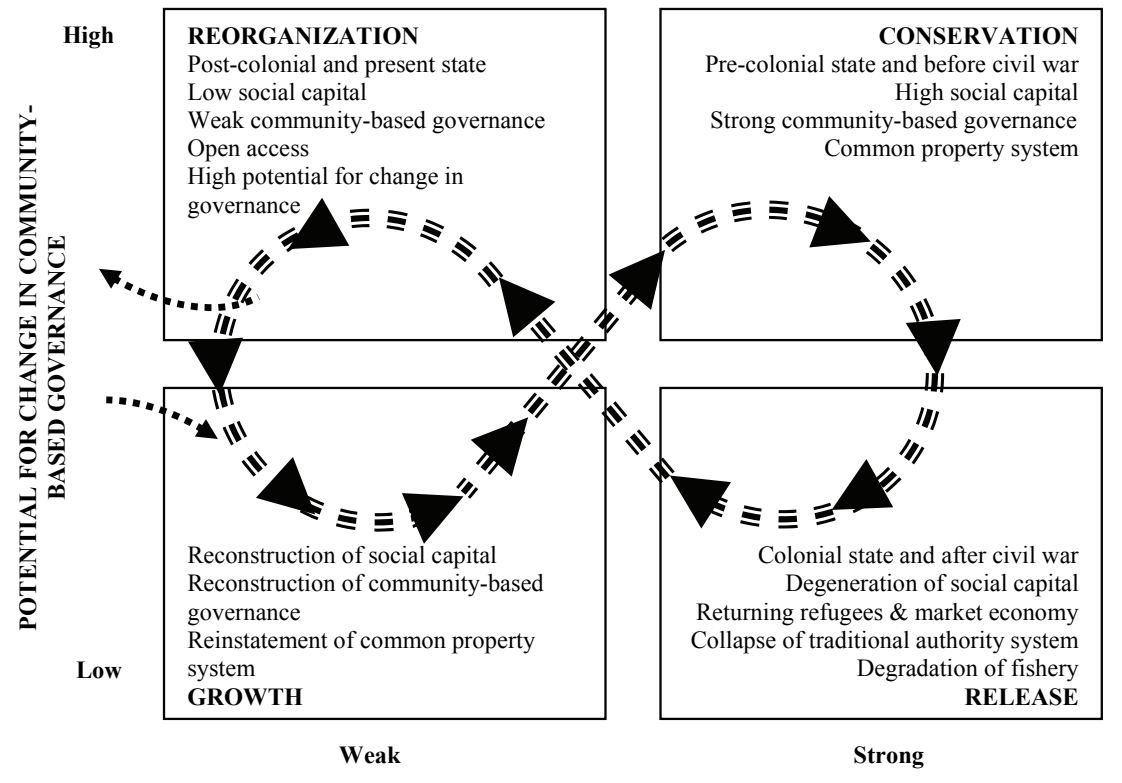

SOCIAL CAPITAL
Figure 2

The resilience model is presented to illustrate the adaptations that have occurred in the Rovuma communitybased governance system and those necessary to reinstate a common property resource system are postulated (adapted from Holling, 1995). 
sible in the conservation phase to find parties who offer benefits to others even when they get nothing tangible in return. Even if such behaviours may encourage mutual cooperation, they are not necessarily altruistic in nature. Although it is impossible to predict the timescale on which a particular property rights regime would reach a conservation phase, it is important to note that cooperative behaviours in this phase are the emergent result of continuing interactions between parties (Axelrod, 1984). Such interactions are based on exchanges that may not necessarily involve material artefacts, but also other intrinsic behavioural variables such as bribes, promises, gifts, rewards, and even sanctions.

It is within this understanding that we suggest that, during the pre-colonial period but before the Mozambican civil war, the Rovuma community-based governance system was in a conservation phase (Fig. 2). The study revealed that during this period there were strong internal links within the community reflecting highly developed social capital. Under these conditions, rights of access and fishing practices were regulated and the fishery operated as a common property resource. The interviews conducted for this study showed that in those times the Chief determined who could fish and that groups of fishermen would have 'exclusive rights' to fish a particular area. Respondents elaborated that people from outside the community had to approach the Chief for permission to fish and that if this was granted they would make a gift of fish to the Chief, particularly when leaving the area. Failure to comply could bring bad luck in fishing and perhaps even more serious misfortune (Abacar, 2000). The responses of the elders further revealed that the traditional fishery was characterised by clear distinction of a 'group of users' to whom property was common. This property rights regime allowed for the establishment of rules that governed access to and use of the property. Thus, it is suggestive that the Rovuma community-based governance system during this phase operated under a property rights regime that provided for the management of relationships between people. Hence, the assumption that social capital was relatively high during this phase.

\section{Release phase}

As the community-based governance system progressively became more conservative, and thus more vulnerable to change, the conservation phase gave way to release. Resilience theorists refer to this new emergent phase as adversarial (Nkhata et al., 2008) when the capacity for change is low as the social capital begins to degenerate due to growth in adversarial behaviour. While the property rights under this phase may still be founded on relatively high levels of social capital, the potential is high for the regime to generate conflict, which is associated with significant administrative and coordination costs (Lubell, 2004). Although the sources of conflict may be beyond the control of members of the community, the progressive degeneration of social capital may lead to the deinstitutionalisation of property rights. It is for this reason that we postulate that the nature of the property rights under a release phase is important in elucidating the governance of common property.

We characterise the period during the colonial administration but after the Mozambican civil war as a release phase (Fig. 2). During this period, the Rovuma community-based governance system started to exhibit signs of ineffective or absence of regulations. The elders interviewed indicated that the community-based governance system during this period was no longer effective. They noted that the attitudes and behaviours of the community members had changed from ones that viewed the fishery as a supplier of food to one that saw it as a commercial entity. The elders elaborated that self-interest had led to an erosion of cultural identity of community and group ownership over the resource. The Mozambican civil war in the post-colonial era drove many people into exile in Tanzania leading to local linkages being weakened. While the arrival of the Catholic Church might have led to new external linkages, the Church had little effect on social capital because its belief system was strongly resisted. By contrast, the introduction of a market economy by the colonial administrators as well as the return of the refugees from camps in Tanzania after the end of the civil war had affected the property rights regime. The N'dunas, who previously were mere headmen, started to behave like Mwenyes (Chiefs) and instead of going back to their original locations chose to settle elsewhere so they could gain more power and influence. It was claimed that the collapse of power relations fractured the community by weakening traditional norms and values as well as trust and commitment among community members, which in turn affected the property rights regime.

This situation led to the degradation of the fishery. The respondents revealed that fish catches during this period had declined. They indicated that most of the fishermen were seen to change fishing sites to follow availability of stocks. It was observed that there was total disregard of the significance of spawning sites which were previously designated as no fishing areas. Declining catches against an ever-growing demand for fish as a source of protein for the locals and the commercial market created unprecedented competition over limited fish resources. The respondents claimed that competition among fishermen was a major problem. The desire to out-compete other fishermen had encouraged the use of practices previously considered inappropriate. Small meshed gill nets, hooks, poison plants and traps were used to capture fish.

It could be argued that the increase in societal heterogeneity was perhaps the main driver for the release. It changed internal relationships and weakened further the social capital thereby deinstitutionalising the common property rights that had been undermined during the colonial period. When respondents were asked to indicate the implications of the introduction of external social forces, the elders observed that this influenced the relationships among people. They elaborated that as most people could not read or write Portuguese at the time they were afraid and could not express opinions. They further claimed that illiteracy was a mechanism they used to resist change to Christianity to the extent that they would also not attend school. It also helped them to avoid eating pork as was forbidden by their Muslim faith. The findings suggest that at one time there were strongly developed norms, relationships, trust and respect. However, even in these early times the new social forces challenged the property rights regime.

\section{Reorganisation phase}

Reorganisation, in the context of resilience theory, is a phase when a community-based governance system is reorganised through the emergence of new tactics and opportunities. During this phase, whereas the capacity for change is high due to the re-strengthening of social capital, the property rights regime would still be regaining focus. Depending on particular conditions, reorganisation may lead to a shift into a new configuration of less or more cooperative behaviours.

Reorganisation in the Rovuma community-based governance system is evidenced in the present state of the post-colonial era (Fig. 2). In the present state, the social capital is relatively 
low and the property rights regime is generally operating as open access. The elders interviewed during this study claimed that this situation has emerged due to the fact that traditional institutions were undermined during the colonial period. They claimed that at the time of the interviews there were no controls regulating access and use. They elaborated that people no longer seek permission from the Chief and that non-traditional methods such as the use of poisons, have continued to be introduced to maximise catch. One of the elders commented that control over use is now the responsibility of government and that the power of Chiefs is limited to mediation. When fishermen were asked whether there were ways in which the situation could be improved, they suggested that going back to the older property regime through support of traditional controls could help. They suggested that the creation of local committees and co-management could provide a solution, in a way indicative of the influence of the Chipanje Chetu CBNRM initiative, which is currently being implemented in the area.

The aim of the Chipanje Chetu CBNRM initiative has been 'the transfer of rights and responsibilities for land and resource management to local level user groups (a village community or group from within a village)' (Anstey, 2005:183). Although not explicitly stated, this may also have the intention of rebuilding social capital. The fishery now has elements necessary for the development of a complex common property rights system in which some claim traditional rights and others claim rights through use. In such a contested situation, it is hard to envisage establishing an effective management process until there is agreement on rights and governance. But this also requires that trust, respect, norms and authority that are supportive of community-based governance are established.

The fisheries policy of the Mozambiqican Government declares the intention to promote the formation of artisanal comanagement committees in areas exhibiting over-fishing (Institute for Development of Fisheries of Small Scale, IDDPE, 1999a and b). The Rovuma River fishery is artisanal and qualifies for co-management. In this way, distinction can be drawn between the process of co-managing and the manner of governing the process (Imperial, 2005). Co-management seeks to establish a process of management in which the manner of governing is characterised by devolution of authority, roles and responsibilities to those who can rightfully claim ownership (not necessarily use) of the resource. The manner of governing the process (governance) has particular significance in the process of managing the use of common property. This is because of the importance of networking among stakeholders to build and sustain trust, commitment, respect, leadership and shared norms that provide a foundation for governance. In other words, governance and social capital are strongly interdependent and both need to be nurtured by stakeholders (Imperial and Kauneckis 2003).

\section{Forces directing change}

In postulating a change from common property to an open access regime it was necessary to postulate the probable forces that directed change. These are illustrated in Fig. 3. From the perspective of this study, the earliest force is considered to be colonisation by the Portuguese in the late 1800 s. This would undermine the governance system (Harrison, 2002; Anstey, 2005) and the social capital that sustained it by weakening traditional authority and concomitant breakdown of trust, commitment and norms among community members. By contrast, the Muslim faith and its associated values and norms reinforced social capital especially as the pressure for conversion by the Catholic Church to Christianity and to speak Portuguese (Anstey, 2005) fostered resistance (Abacar, 2000), thereby engendering cohesion within society. We postulate, however, that the overriding consequence was a weakening of governance reflected in controls over the fishery, as has happened in other similar situations (see Hara, 2005).

Our premise is that the fishery increasingly came under the influence of a market economy driven largely by increasing demand and reinforced by associations of returning refugees (Abacar, 2000; Anstey, 2005). Integration of subsistence fisheries into market economies, where profit motivates exploitation, makes it increasingly difficult to apply controls (Hara and

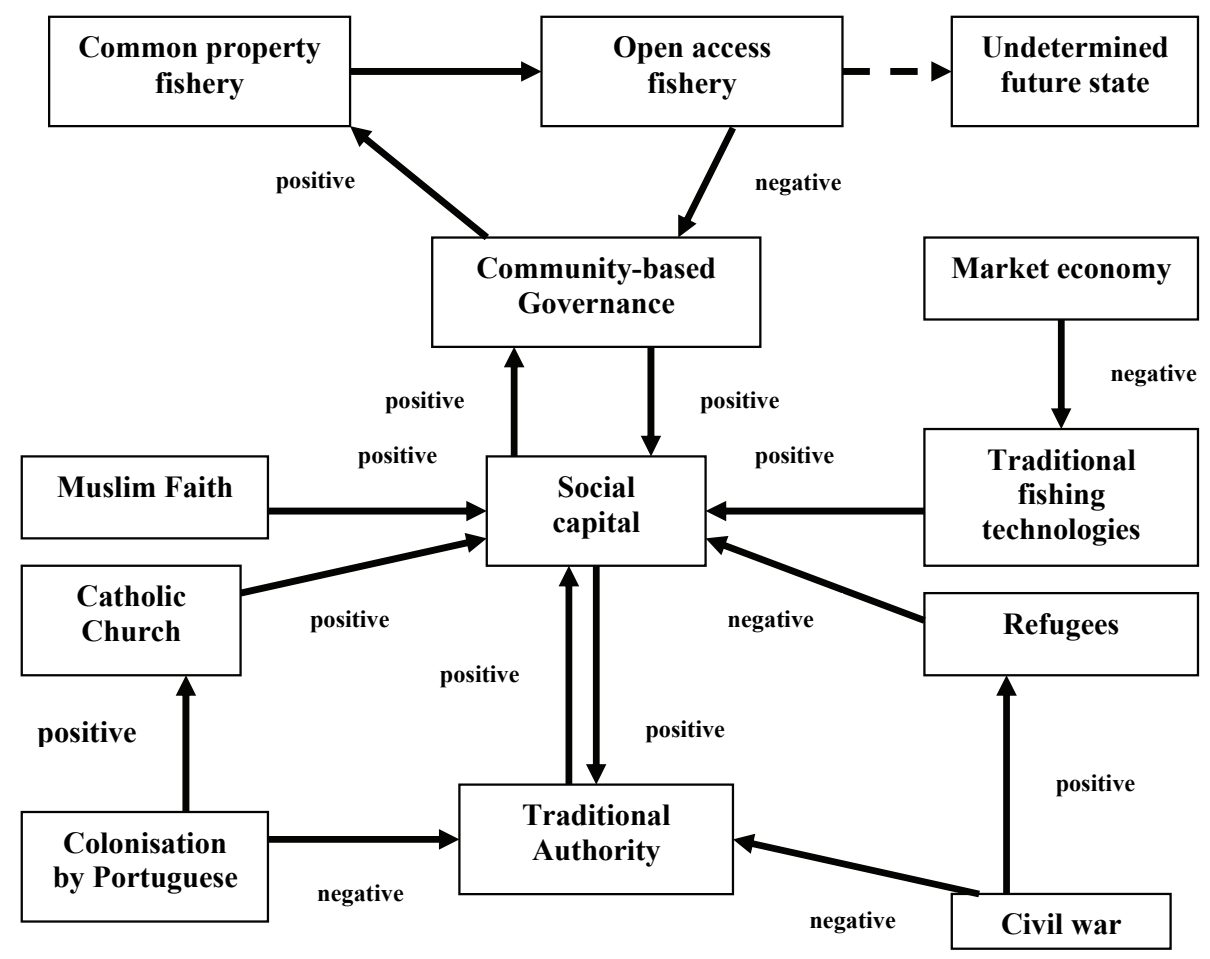

Figure 3

Postulated forces driving the fishery from a common property resource system to an open access system. Social capital is posited as a foundation for communitybased governance in the pre-colonial era. 
Nielsen, 2003). Hara (2005:49), considering two fisher communities in Malawi (also Yao and mostly Muslim), observed that under the influence of a market economy we should not unquestioningly assume continued existence of a 'rural community' character and traits such as unity, homogeneity, coherence and stability, much less the capacity to engage in and carry out collective action. Thus, one would argue that the influx of 'foreign' people into the Rovuma area and transformation of the artisanal fishery by new market forces would together have exerted profound negative effects on social capital and subsequently community-based governance. Weakening control facilitated transition from common property to open access. This resulted in the breakdown of the processes of allocating rights and regulating use so that anyone could access the resource, with each individual deciding independently as this allowed the property rights regime to operate with low transactional costs.

In sum, the foregoing is indicative of a deconstruction of social capital and a breakdown of legitimacy leading to open access. This is as a result of a number of interlinked factors; traditions and authority have been weakened; the definition and cohesion of the group of fishermen have been disrupted; tenure over the resource is no longer defined either in location or in person; and there is no legitimate control over who harvests where, when, how and how much. It is even not possible to sanction those that are clearly breaching the norms and traditional regulations for fishing. Consequently, there is a self-reinforcing cycle resulting from a lack of sanctioning with more and more people engaging in inappropriate fishing practices.

\section{Conclusion}

In this paper we have examined the effects of social capital on the governance processes of CBNRM. We have attempted to illustrate how social capital lends support to the attributes of governance in the use and management of common property resources. In so doing, we have shown that social capital directly affects relationships within a governance system. This is particularly important as it suggests that social capital serves to buffer against destructive change in property rights regimes that would threaten sustainability. As demonstrated in the Rovuma case, decreased social capital lowered the effectiveness of property rights and allowed 'individualistic' behaviours, shifting the system into an open-access regime. The governance system, characterised by low social capital, weak community-based governance and an open access fishery, was not able to maintain those properties that would confer resilience. Whilst there is high potential for change from this phase (Nkhata et al., 2008), and indeed the Chipanje Chetu CBNRM initiative seeks to bring about such change, we suggest that this will be achieved only when social capital and community-based governance have been strengthened.

This study illustrates the value of social capital in managing the use of the resource prior to colonisation. It also shows that social capital was the foundation for resilience enabling the people to resist efforts to introduce Christianity so that they retained their Muslim faith. Whilst in the past there may have existed a strong sense of 'community' sustained by social capital that enabled it to deal with differences and conflicts (the classic surprises of Fabricius and Collins, 2005) the evidence suggests that this is no longer the case. In the area of north Sanga, Anstey (2005:182) observes that governance has 'limited and varied local influence on either customary or state administration' and there is a 'chasm between formal and informal systems and general vacuum and suspicion of authority'. While Fabricius and Collins (2005) have suggested that natural and social capital are commonly well represented in CBNRM initiatives, it may be justified to claim that in many instances such initiatives do not automatically enhance natural and social capital. On the other, it may be reasonable to contend that it is practically possible to re-establish natural and social capital in situations where they have both been depleted. In such situations, we postulate that progress may be significantly enhanced if reconstruction of social capital was addressed explicitly and specifically.

This study is particularly instructive in that it demonstrates that it is in the nature of complex systems that they will exhibit non-linear behaviour (Gunderson and Holling, 2002; Ostrom and Janssen, 2002; Walker, 1989). The Rovuma fishery illustrates a period of monopoly followed by collapse under the influence of intersecting forces (see also Abel, et al., 2006; Nkhata, et al., 2008). The Chipanje Chetu CBNRM initiative suggests reorganisation. However, insofar as the fishery is concerned, it is too early to perceive growth toward a new state. What seems inevitable is that the new state will differ very significantly from the former state even if it is returned to a common property system. Such transformations have been recorded elsewhere such as in watershed governance in the Lake Thaoe Basin (Imperial and Kauneckis, 2003), in transnational rivers management in the Zambezi River basin (Turton et al., 2005) and collaborative wildlife management in Namibia (Jones, 2005).

\section{Acknowledgements}

Nyambe Nyambe, Ernita van Wyk and anonymous reviewers provided useful comment and insight on an earlier draft. We also acknowledge Ruth Howison for assistance with the map.

\section{References}

ABACAR AJ (2000) A Case of Inland Fisheries Management in the Lucheringo-Rovuma-Messinge River Systems, Northern Niassa, Mozambique: From Open to Common Property. Unpublished Master's thesis submitted to the Centre for Environment and Development, University of Natal, South Africa, Pietermaritzburg.

ABEL N, CUMMING DHM, and ANDERIES JM (2006) Collapse and reorganization in social-ecological systems: Questions, some ideas, and policy implications. Ecol. Soc. 11 (1) 17. http://www.ecologyandsociety.org/vol11/iss1/art17/

AMARAL MG (1990) O Povo Yao (The Yao People). Centro de Documentacao e Informacao do IICT, Portugal, Lisbon.

ANDERIES JM, JANSSEN MA and OSTROM E (2004) A framework to analyze the robustness of social-ecological systems from an institutional perspective. Ecol. Soc. 9 (1) 18. http://www.ecologyandsociety.org/vo199/issl/art18.

ANSTEY S (2005) Governance, Natural Resources and Complex Adaptive Systems: A CBNRM Study of Communities and Resources in Northern Mozambique. In: Dzingirai V and C Breen (eds.) Confronting the Crisis in Community Conservation: Case Studies from Southern Africa. Centre for Environment, Agriculture and Development, University of KwaZulu-Natal, South Africa, Pietermaritzburg.

AXELROD R (1984) The Evolution of Cooperation. Basic Books, Inc., New York.

BABBIE E (1995) The Practice of Social Research. (6th edn.) Wadsworth, Belmont. 284-310.

BERKES F, COLDING J and FOLKE C (eds.) (2003) Navigating Social-Ecological Systems, Building Resilience for Complexity and Change. Cambridge University Press, Cambridge.

BROMLEY DW (1991) Environment and Economy: Property Rights and Public Policy. Blackwell, Cambridge, USA.

BUNN D and AUSLANDER M (1998) From Crook's Corner to Thulamela. In: Voices, Values, and Identities. Record of the Proceedings. 25-27 August, Kruger National Park, South Africa. Pretoria, South African National Parks, South Africa. 32-40. 
CAMPBELL, BA, MADONDO N, NEMARUNDWE N, SITHOLE B, DE JONG W, LUCKERT M and MATOSE F (2001) Challenges to proponents of common property resources systems: Despairing voices from the social forests of Zimbabwe. World Dev. 29589 600.

CARLSSON L and BERKES F (2005) Co-management: concepts and methodological implications. J. Environ. Manage. 75 65-76.

COLEMAN JS (1990) Foundations of Social Theory. The Belknap Press of Harvard University Press, Cambridge.

COUSINS PD (2002) A conceptual model for managing long-term inter-organizational relationships. Eur. J. Purchasing Supply Manage. 8 71-82.

DEKKER P and USLANER E (eds.) (2001) Social Capital and Participation in Everyday Life. Routledge, London.

DZINGIRAI V and BREEN C (eds.) (2005) Confronting the Crisis in Community Conservation: Case Studies from Southern Africa. Centre for Environment, Agriculture and Development, University of KwaZulu-Natal, South Africa, Pietermaritzburg.

FABRICIUS C (2004) The fundamentals of community-based natura resource management. In: Fabricius C, Koch E, Magome H, and Turner S (eds.) Rights, Resources and Rural Development: Community-Based Natural Resource Management in Southern Africa. Earthscan, London.

FABRICIUS C and COLLINS C (2005) Community-based Natura Resource Management: Governing the Commons. Symposium Manuscripts: International Symposium on Ecosystems Governance. 10-13 October, Kwa-Maritane, South Africa. CSIR, Pretoria.

GADGIL M, HEMAM NS and REDDY BM (1998) People, refugia and resilience. In: Berkes F and Folke C (eds.) Linking Social and Ecological Systems: Management Practices and Social Mechanisms for Building Resilience. Cambridge University Press, Cambridge.

GIBBS CJN and BROMLEY DW (1989) Institutional arrangements for management of rural resources: Common property regimes. In Berkes F (ed.) Common Property Resources-Ecology and Community-based Sustainable Development. Bellhaven Press, London.

GRANOVETTER M (1985) Economic action and social structure: The problem of embeddedness. Am. J.Sociol. 91481 -510.

GUNDERSON LH and HOLLING CS (eds.) (2002) Panarchy: Understanding Transformations in Human and Natural Systems. Island Press, Washington

HARA M (2005) Participatory fisheries management in Lake Malombe and the upper Shire River - Malawi. In: Dzingirai V and Breen C (eds.) Confronting the Crisis in Community Conservation: Case Studies from Southern Africa. Centre for Environment, Agriculture and Development, University of KwaZulu-Natal, South Africa, Pietermaritzburg

HARA M and NIELSEN JR (2003) Experiences with fisheries comanagement initiatives. In: Wilson DC, Nielsen JR, and Degnbol $\mathrm{P}$ (eds.) The Fisheries Co-management Experience: Accomplishments, Challenges and Prospects. Kluwer Academic Publishers, Dordrecht, Netherlands.

HARRISON G (2002) Traditional power and its absence in Mecufi, Mozambique. J. Contemp. Afr. Studies 20 (1) 107-130

HOLLING CS (1973) Resilience and Stability of Ecological Systems. Ann. Rev. Ecol.Syst. 4 1-23.

HOLLING CS (1995) What Barriers? What Bridges? In: Gunderson, LH, CS Holling, and SS Light (eds.) Barriers and Bridges to the Renewal of Ecosystems and Institutions. Columbia University Press, New York.

HUXHAM C (ed.) (1996) Creating Collaborative Advantage. Sage, Publications, London.

IDDPEM (1999a) Draft do relatorio final do IPPE (IDDPE Draft Report). Unpublished Report. Mozambique, Maputo.

IDDPEM (1999b) Sintese do Seminario Nacional Sobre a Co-gestao das Pescarias Artesanais em Mocambique (Synthesis for the National Seminar Co-Management of Artisanal Fisheries. Unpublished Report. Mocambique, Maputo

IUCN (1998) Ten Principles of Chipanje Chetu. Internal Project Document, IUCN Mozambique, Maputo.

IMPERIAL MT (2005) Using collaboration as a governance strategy: Lessons form six watershed management programs. Admin. Soc. 37 (3) $281-320$
IMPERIAL MT and KAUNECKIS (2003) Moving from Conflict to Collaboration: Lessons from the Lake Tahoe Experience. Nat. Resour. J. 43 (4) 1009-1005.

JODHA NS (1998) Reviving the social system-ecosystem links in the Himalayas. In: Berkes F and Folke C (eds.) Linking Social and Ecological Systems: Management Practices and Social Mechanisms for Building Resilience. Cambridge University Press, Cambridge.

JONES BT (2005) Community-based natural resources management (CBNRM): The Case of Namibia. In: Dzingirai V and Breen C (eds.) Confronting the Crisis in Community Conservation: Case Studies from Southern Africa. Centre for Environment, Agriculture and Development, University of KwaZulu-Natal, South Africa, Pietermaritzburg.

KINNAMAN ML and BLEICH MR (2004) Collaboration: Aligning resources to create and sustain partnerships. J. Prof. Nursing 20 310-322

KNOKE D (1990) Political Networks: The Structural Perspective. Cambridge University Press, New York.

KOCH E (2004) Putting out fires: does the ' $C$ ' in CBNRM stand for community, or centrifuge? In: Fabricius C, Koch E, Magome $\mathrm{H}$ and Turner S (eds.) Rights, Resources and Rural Development: Community-Based Natural Resource Management in Southern Africa. Earthscan, London.

KUMAR K (1989) Conducting Key Informant Interviews in Developing Countries. Agency for International Development, Washington DC.

LEACH MR, MEARNS R and SCOONES I (1997) Challenges to community-based sustainable development: dynamics, entitlements, institutions. IDS Bull. 28 (4) Institute for Development Studies. Sussex.

LUO Y (2002) Building Trust in Cross-Cultural Collaborations: Towards a Contingency Perspective. J. Manage. 28 (5) 669-694.

LUBELL M (2004) Resolving Conflict and Building Cooperation in the National Estuary Program. Environ. Manage. 33 (5) 677-691.

MEINZEN-DICK RS, BROWN LR, FELDSTEIN HS and QUISUMBING AR (1997) Gender, Property Rights and Natural Resources. World Dev. 25 1303-1315.

METCALFE S (1994) The Zimbabwe communal areas management programme for indigenous resources. In: Western D, Wright RM and Strum SC (eds.) Natural Connections: Perspectives in Community-Based Conservation. Island Press, Washington.

NEWMAN L and DALE A (2005) Network structure, diversity and proactive resilience: A response to Tompkins and Adger. Ecol. Soc. 10 (1) r2 http://www.ecologyandsociety.org/vol10/iss1/resp2.

NKHATA AB, BREEN CM and FREIMUND W (2008) Resilient social relationships and collaboration in the management of social-ecological systems. Ecol. Soc. 13 (1) 2 http://www.ecologyandsociety.org/ vol13/1iss1/art2

OKELLO MM and KIRINGE JW (2004) Threats to Biodiversity and their Implications in Protected and Adjacent Dispersal Areas of Kenya. J. Sustain. Tourism 12 55-69.

OSTROM E (1990) Governing the Commons: Evolution of Institutions for Collective Actions. Cambridge University Press, Cambridge.

OSTROM E and JANSSEN MA (2002) Beliefs, Multi-level Governance and Development. Working Paper for the Workshop on Political Theory and Policy Analysis. Indiana State University, Bloomington.

PETTIGREW AM (1973) The Politics of Organizational Decision Making. Tavistock, London.

PETTIGREW AM (1990) Longitudinal Field Research on Change: Theory and Practice. Organ. Sci. 1 (3) 267-292.

PLUMMER R and FITZGIBBON J (2006) People matter: The importance of social capital in the co-management of natural resources. Nat. Resour. Forum 30 51-62.

PUTNAM RD (1993) Making Democracy Work: Civic Traditions in Modern Italy. Princeton University Press, Princeton.

RHODES RAW (1996) The new governance: governing without government. Polit. Studies 44 652-667.

ROBBINS P (2000) The rotten institution: corruption in natural resource management. Polit. Geog. 19 423-443.

SAUNDERS MNK, LEWIS P and THORNHILL A (1997) Research Methods for Business Studies. Pitman, London. 
SCHLAGER E and OSTROM E (1992) Property-rights regimes and natural resources: a conceptual analysis. Land Econ. 68 249-262.

SINGLETON M (1998) Constructing Cooperation: The Evolution of Institutions of Comanagement. University of Michigan Press, Ann Arbor.

SINGLETON M and TAYLOR M (1992) Common property, collective action and community. J. Theor. Polit. 4 309-324.

STOKOWSKI PA (2003) Community Values in Conservation. In: Minteer B and Manning R E (eds.) Reconstructing Conservation: Finding Common Ground. Island Press.Washington.

STRAUSS A and CORBIN J (1998) Basics of Qualitative Research: Techniques and Procedures for Developing Grounded Theory (eds.) Sage Publications, Thousand Oaks, California.

TURNER S (2004a) Community-based natural resources management and rural livelihoods. In: Fabricius C, Koch E, Magome $\mathrm{H}$ and Turner S (eds.) Rights, Resources and Rural Development: Com- munity-based Natural Resource Management in Southern Africa. Earthscan, London.

TURNER S (2004b) A land without fences: range management in Lesotho. In: Fabricius C, Koch E, Magome H and Turner S (eds.) Rights, Resources and Rural Development: Community-based Natural Resource Management in Southern Africa. Earthscan, London.

TURTON A, HATTINGH H, CLAASEN M, ROUX D and ASHTON P (2005) Towards a Model for Ecosystem Governance: An Integrated Water Resource Management Example. In: Turon AR, Hattingh H, Maree G, Roux D, Claasen M and Strydom WF (eds.) Governance as a Trialogue: Government-Society-Science in Transition. Springer, Berlin, Heidelberg, New York.

WALKER BH (1989) Diversity and stability in ecosystem conservation. In: Western D and Pearl M (eds.) Conservation for the Twenty-First Century. Oxford University Press, New York. 
Available on website http://www.wrc.org.za ISSN 0378-4738 = Water SA Vol. 35 No. 1 January 2009

ISSN 1816-7950 = Water SA (on-line) 